Bangladesh J. Bot. 41(1): 105-110, 2012 (June)

\title{
KARYOTYPE AND RAPD ANALYSIS IN FIVE POTATO VARIETIES (SOLANUM TUBEROSUM L.)
}

\author{
Riffat Ara Alam, Md Ahashan Habib and Sheikh Shamimul Alam* \\ Department of Botany, University of Dhaka, Dhaka-1000, Bangladesh
}

Key words: Karyotype, RAPD, Solanum tuberosum

\begin{abstract}
Two native and three high yielding potato varieties available in Bangladesh were studied cytogenetically at molecular level to get a preliminary idea about their genomes. These varieties possess $2 \mathrm{n}=4 \mathrm{x}=48$ chromosomes. Each variety has definite centromeric formula. Presence of maximum metacentric chromosomes suggested their karyotypes as symmetric type. The range of individual chromosomal and total length of $2 \mathrm{n}$ chromosome complements was also distinct in five varieties. Heteromorphicity regarding centromeric position suggesting the occurrence of structural aberration in respective homologous pairs. Seven primer combinations were used for RAPD finger printing. A few common RAPD bands suggested the sharing of genomic fragments among five varieties. However, each variety showed specific characteristic RAPD bands. Therefore, each variety has characteristic karyotype and RAPD markers.
\end{abstract}

\section{Introduction}

The genus Solanum L. has 160 species of which eight are cultivated and belong to the series tuberosa. The cultivated potato is a starchy tuberous crop. Potato varieties cultivated in Bangladesh are broadly categorized into two groups - (i) local and (ii) high yielding. There are about 27 local varieties of potatoes cultivated in different parts of Bangladesh (Islam et al. 2003). In the last few decades, several dozens of high yielding varieties (HYV) of potato were brought to Bangladesh and tried experimentally under local conditions before being recommended for general cultivation (Islam et al. 2003).

Solanum tuberosum L. usually is a tetraploid with $2 \mathrm{n}=4 \mathrm{x}=48$ chromosomes (Hawkes 1990). However, there is no report of $2 \mathrm{n}$ and ploidy level of the native and high yielding variety of potatoes found in Bangladesh. Karyotype analysis often plays an important role in determining the taxonomic status of a taxon where the taxonomic parameters are insufficient. During karyotype analysis, the problem usually arises when different taxa possess same chromosome numbers and almost similar karyotype features. In this situation, it is hard to distinguish between such taxa by conventional karyotype analysis. Even the consideration of chromosome length, arm ratio, position and number of secondary constrictions are not always sufficient to differentiate individual chromosome.

In such a case, DNA finger printing by Randomly Amplified Polymorphic DNA (RAPD) is another method for characterizing germplasms authentically. The term DNA fingerprinting/ profiling describes the combined use of several single locus detection systems. This method has been using as versatile molecular tool for investigating various genomic aspects of organism. RAPD markers generated by the polymerase chain reaction (PCR), has been widely using since late 1980's of the last century to assess intraspecific genetic variation on a molecular level (Welsh and McClelland 1990, Williams et al. 1990).

A combined karyotype and RAPD analysis may provide data of different dimension about the genomes of potato. Therefore, the aim of the present study was (i) to find out $2 \mathrm{n}$ chromosome

*Author for correspondence: <ssalam81@yahoo.com> 
number of each variety, (ii) to elucidate ploidy level, (iii) to find other karyotype features, (iv) to make a RAPD finger printing and (v) to construct a phytogenetic dendogram on the basis of RAPD finger printing.

\section{Materials and Methods}

Five varieties of potato such as Jaam, Laal Sheel, Diamant, Cardinal and Granola were studied in this experiment (Fig. 1a-e). Jaam and Lal Sheel varieties were collected from Mymensingh and Bogra, respectively. Whereas, Diamant, Cardinal and Granola were collected from Bangladesh Agricultural Research Institute (BARI). All these varieties were germinated and maintained in the Botanical garden, Department of Botany, University of Dhaka, Bangladesh.

Healthy roots were collected and pretreated with $0.002 \mathrm{M}$ 8-hydroxyquinoline for $30 \mathrm{~min}$ at $18^{\circ} \mathrm{C}$ followed by 15 min fixation in $45 \%$ acetic acid at $4^{\circ} \mathrm{C}$. These were then hydrolysed in a mixture of $1 \mathrm{~N} \mathrm{HCl}$ and $45 \%$ acetic acid $(2: 1)$ at $60^{\circ} \mathrm{C}$ for 20 sec. The root tips were stained and squashed in $1 \%$ aceto-orcein for $2 \mathrm{~h}$ at room temperature and squashed.

Leaves were harvested and total genomic DNA was extracted by using modified CTAB method (Doyle and Doyle 1987). DNA concentration was quantified through spectrophotometer (Analylikjena, Specord 50, Germany). The A260/280 readings for DNA samples were 1.6 - 1.8.

The PCR mix for $25 \mu$ l containing template DNA (25 ng) $2 \mu$ l, de-ionized distilled water 18.8 $\mu \mathrm{l}$, Taq buffer A 10X (Tris with $15 \mathrm{mM} \mathrm{MgCl}$ ) $2.5 \mu \mathrm{l}$, primer $(10 \mu \mathrm{M}) 1.0 \mu \mathrm{l}$, dNTPs $(2.5 \mathrm{mM})$

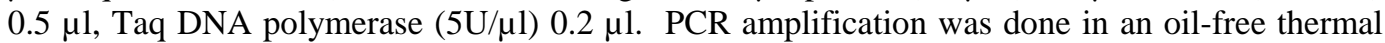
cycler (Biometra UNOII, Germany) for 46 cycles after initial denature $94^{\circ} \mathrm{C}$ for $5 \mathrm{~min}$, denature at $94^{\circ} \mathrm{C}$ for $1 \mathrm{~min}$, annealing at $36^{\circ} \mathrm{C}$ for $30 \mathrm{sec}$, extension at $72^{\circ} \mathrm{C}$ for $3 \mathrm{~min}$ and final extension at $72^{\circ} \mathrm{C}$ for 5 min. Seven primers were used from Operon Technologies, USA as batch-7736030(GAAACGGGTG), batch-7736-031(GTTGCGATCC), batch-7736-032(TGCCGAGC TG), batch-7736-033(GGGTAACGCC), batch-7736 045(CAAACGTCGG), batch-7736-050(GG CACTGAGG) and batch-7736-051(CTCTCCGCCA).

The amplified products were separated electrophoretically on $1 \%$ agarose gel. The gel was prepared using $1.0 \mathrm{~g}$ agarose powder containing ethidium bromide $8 \mu \mathrm{l}$ and $100 \mathrm{ml} 1 \times \mathrm{TAE}$ buffer. Agarose gel electrophoresis was conducted in $1 \times$ TAE buffer at 50 volts and $100 \mathrm{~mA}$ for $1.5 \mathrm{~h}$. DNA ladder $1 \mathrm{~kb}$ was electrophoresed alongside the RAPD reactions as marker. DNA bands were observed on UV-transilluminator and photographed by a gel documentation system.

The PCR products were analyzed after gel electrophoresis. The photographs were critically discussed on the basis of presence (1) or absence (0), size of bands and overall polymorphism of bands. These were carried out for further investigation. RAPD analysis was then combined to create a single data matrix. This was used for estimating linkage distance (D) and constructing a UPGMA (Unweighted Pair Group Method of Arithmetic Means) Dendrogram among the varieties using computer program "Statistica". Linkage distances were computed from frequencies of polymorphic markers to estimate genetic relationship between the studied five potato varieties using UPGMA (Lakhanpaul et al. 2000).

\section{Results and Discussion}

The five varieties were found to possess $2 \mathrm{n}=4 \mathrm{x}=48$ chromosomes. The presence of $2 \mathrm{n}$ chromosome number of these five potato varieties was in agreement with earlier report (Hawkes 1990). The occurrence of disomic species suggesting that the cultivated varieties are tetraploids $(2 \mathrm{n}=4 \mathrm{x}=48)$. 

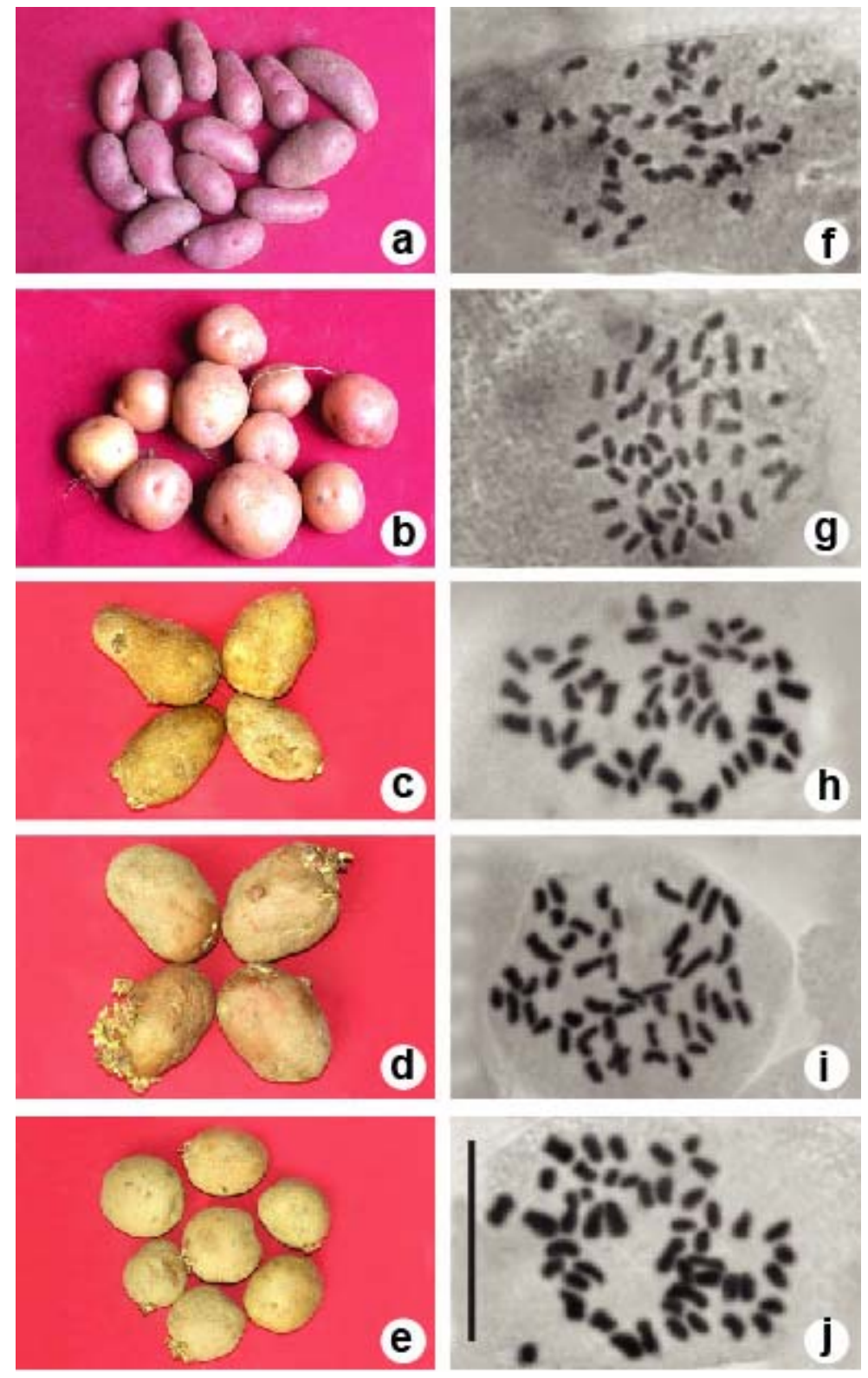

Fig. 1a-e: Photograph of five varieties in Solanum tuberosum. a. Jaam, b. Lal sheel, c. Diamant, d. Cardinal and e. Granola, f-j: Orcein stained metaphase chromosomes of five varieties in Solanum tuberosum. $\mathrm{f}$. Jaam, g. Lal sheel, h. Diamant, i. Cardinal and j. Granola. Bar $=5 \mu \mathrm{m}$ for Fig. $\mathrm{f}-\mathrm{j}$.

The five varieties have definite centromeric formulae but rich in metacentric chromosomes (Table 1). Presence of maximum metacentric chromosomes in the karyotype is a common phenomenon of Solanum spp. (Sultana and Alam 2007). The abundance of metacentric chromosomes is a characteristic of symmetric karyotypes which is primitive in nature (Stebbins 
1971). Therefore, like other Solanum spp. potatoes possessed primitive karyotypes. The total length of 2n chromosome complement and range of individual chromosome length were highest in Lal Sheel and Cardinal followed by Granola and Diamant. These were lowest in the variety Jaam (Table 1).

Table 1. Comparative karyotype analysis of five varieties of Solanum tuberosum.

\begin{tabular}{lcccc}
\hline Varieties & 2n & $\begin{array}{c}\text { Range of } \\
\text { chromosomal length } \\
(\mu \mathrm{m})\end{array}$ & $\begin{array}{c}\text { Total length of 2n } \\
\text { chromosome } \\
\text { complements }(\mu \mathrm{m})\end{array}$ & $\begin{array}{c}\text { Centromeric } \\
\text { formulae }\end{array}$ \\
\hline Jaam & 48 & $0.30-0.89$ & 27.03 & $43 \mathrm{~m}+5 \mathrm{sm}$ \\
Lal Sheel & 48 & $0.52-1.57$ & 41.22 & $43 \mathrm{~m}+5 \mathrm{sm}$ \\
Diamant & 48 & $0.47-1.00$ & 32.57 & $48 \mathrm{~m}$ \\
Cardinal & 48 & $0.52-1.45$ & 41.90 & $34 \mathrm{~m}+14 \mathrm{sm}$ \\
Granola & 48 & $0.32-1.25$ & 38.69 & $44 \mathrm{~m}+4 \mathrm{sm}$ \\
\hline
\end{tabular}

$\mathrm{m}=$ metacentric chromosome, $\mathrm{sm}=$ sub-metacentric chromosome

Except Diamant, heteromorphicity in respect of centromeric position was found in different pairs of the rest four varieties (Table 1). The number of heteromorphicity was varied among these four varieties. Here one member of the homologue was metacentric while the other submetacentric. The heteromorphicity indicates the probable occurrence of deletion of chromosome segment from one member of the respective homologue. Therefore, the structural chromosomal aberration might play a role in varietal diversification.

RAPD is a unique tool for obtaining a clear DNA finger printing of a particular specimen. Each primer combination finds corresponding fragments after PCR reaction. In this study, 7 different primer combinations were tried to get clear polymorphic DNA finger printing in 5 varieties of potato (Table 2). The five varieties showed some common RAPD bands in different

Table 2. RAPD analysis with seven primers in five varieties of $S$. tuberosum.

\begin{tabular}{|c|c|c|c|c|c|c|c|c|c|c|c|c|}
\hline \multirow{2}{*}{$\begin{array}{l}\text { Primers } \\
\text { code }\end{array}$} & \multirow{2}{*}{$\begin{array}{l}\text { Total } \\
\text { no. of } \\
\text { bands }\end{array}$} & \multirow{2}{*}{$\begin{array}{l}\text { No. of } \\
\text { common } \\
\text { bands }\end{array}$} & \multicolumn{5}{|c|}{ No. of polymorphic bands } & \multicolumn{5}{|c|}{ No. of unique bands } \\
\hline & & & Jaam & $\begin{array}{c}\text { Lal } \\
\text { Sheel }\end{array}$ & $\begin{array}{l}\text { Dia- } \\
\text { mant }\end{array}$ & $\begin{array}{l}\text { Car- } \\
\text { dinal }\end{array}$ & $\begin{array}{l}\text { Gra- } \\
\text { nola }\end{array}$ & Jaam & $\begin{array}{c}\text { Lal } \\
\text { Sheel }\end{array}$ & $\begin{array}{l}\text { Dia- } \\
\text { mant }\end{array}$ & $\begin{array}{l}\text { Car- } \\
\text { dinal }\end{array}$ & $\begin{array}{l}\text { Gra- } \\
\text { nola }\end{array}$ \\
\hline Batch-7736-030 & 16 & 2 & 4 & 4 & 4 & - & 4 & 1 & 1 & - & - & - \\
\hline Batch-7736-031 & 16 & 2 & 2 & 2 & - & 1 & - & - & - & - & - & 1 \\
\hline Batch-7736-032 & 09 & 1 & 1 & 1 & 2 & 2 & 2 & - & 1 & - & - & - \\
\hline Batch-7736-033 & 13 & 1 & 3 & - & 4 & 3 & 3 & - & - & 1 & - & 1 \\
\hline Batch-7736-045 & 10 & - & - & 2 & 1 & 2 & - & 1 & 2 & - & - & 2 \\
\hline Batch-7736-050 & 10 & - & - & 2 & 2 & 2 & 2 & 1 & - & - & - & 1 \\
\hline Batch-7736-051 & 19 & - & - & 4 & 7 & 7 & 1 & - & - & - & - & - \\
\hline
\end{tabular}

primer combinations revealing the sharing of similar fragments. This also indicates that those fragments had come from common ancestors (Fig. 2a-d, Table 2). In spite of some common bands, each variety had unique polymorphic bands in different primer combination. These bands were not present in other varieties (Fig. 2a-f, Table 2). Therefore, each variety has its own diagnostic RAPD finger printing. 

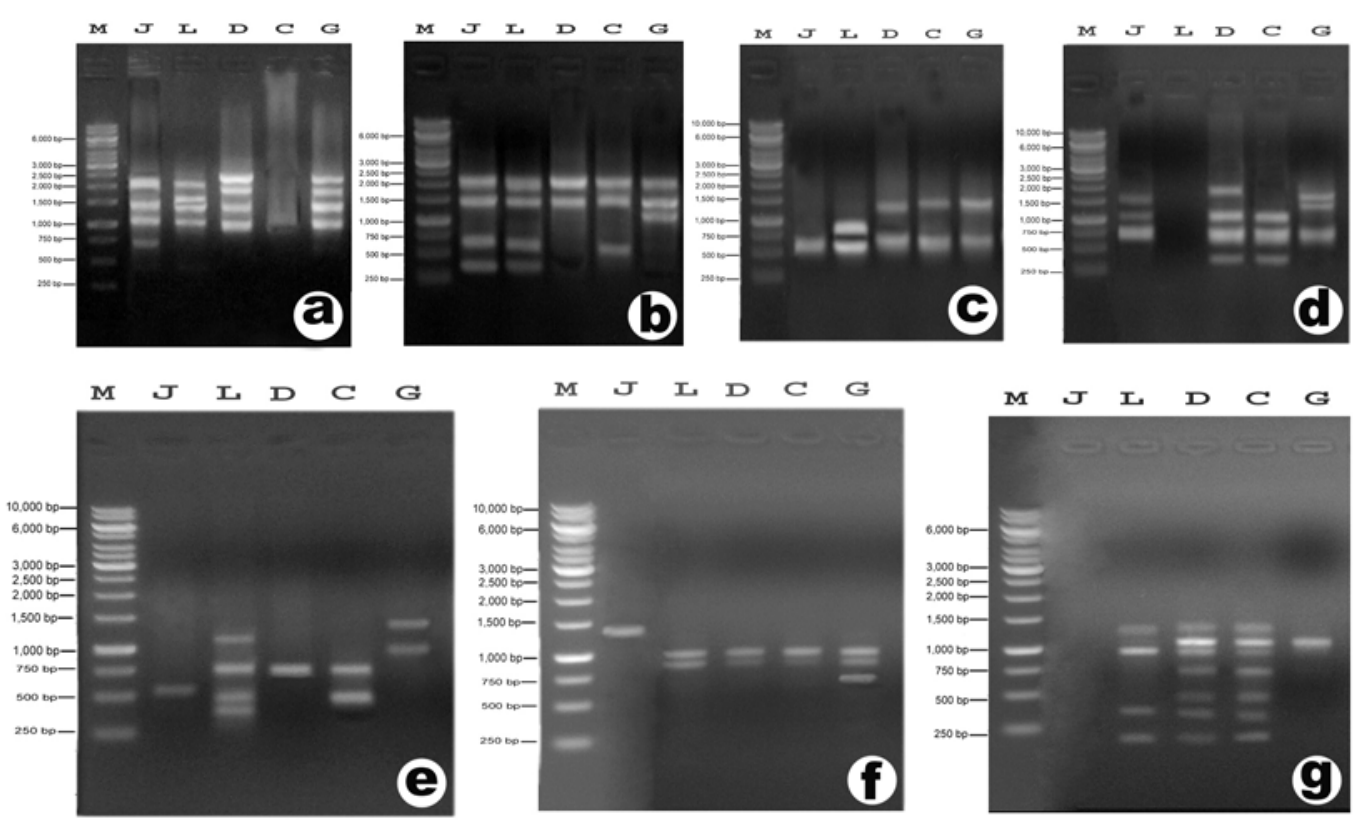

Fig. 2a-g: RAPD analysis. a. primer batch-7736-030, b. primer batch-7736-031, c. primer batch-7736-032, d. primer batch-7736-033, e. primer batch-7736-045, f/. primer batch-7736-050 and g. primer batch7736-051 of five varieties of potato. $\mathrm{M}=1 \mathrm{~kb}$ DNA ladder, $\mathrm{J}=\mathrm{Jaam}, \mathrm{L}=$ Lal sheel, $\mathrm{D}=$ Diamant, $\mathrm{C}=$ Cardinal and $\mathrm{G}=$ Granola.

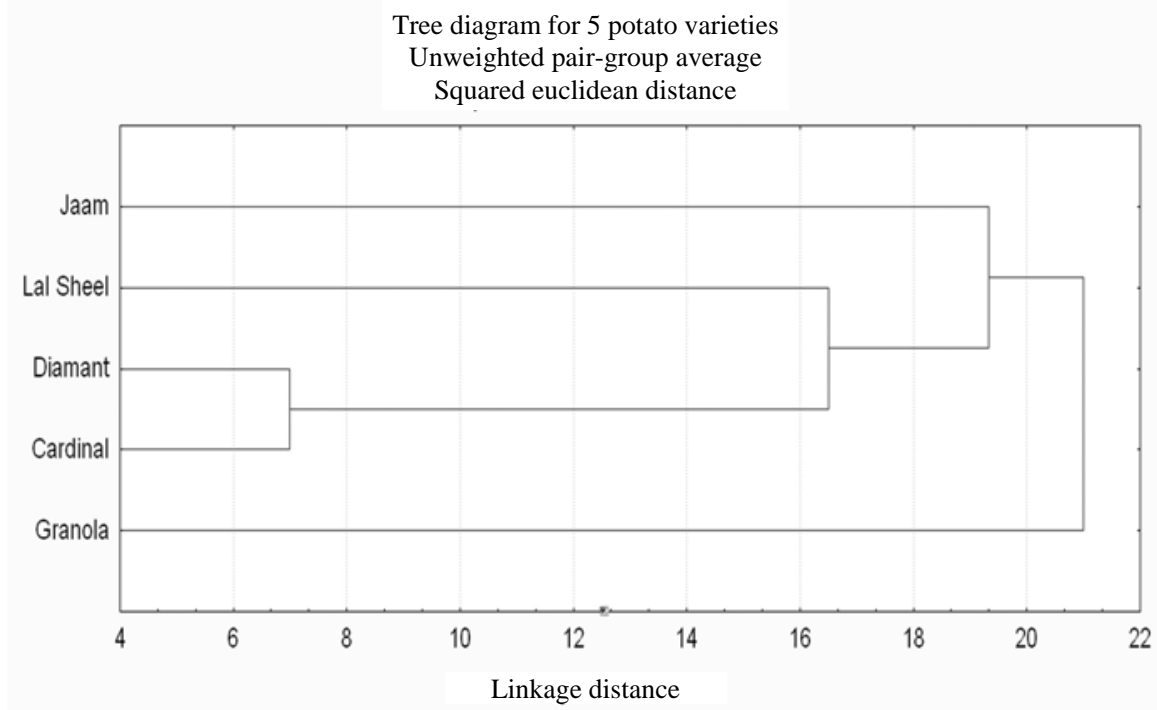

Fig. 3. Cluster analysis by unweighted pair-group method of arithmetic means (UPGMA) of five potato varieties based on seven RAPD markers.

On the basis of RAPD finger printing, a cluster analysis was carried out to elucidate the phylogenetic relationship among the five varieties of potato (Fig. 3). The cluster analysis showed that the variety Granola was totally different from the rest followed by Jaam at linkage distance 
19.0 and Lal Sheel at 16.8. Diamant and Cardinal showed close relationship at linkage distance 7.0. Therefore, it showed that each variety of potato has specific karyotype and RAPD markers.

\section{References}

Doyle JJ and JL Doyle 1987. A rapid DNA isolation procedure from small quantities of fresh leaf tissues. Phytochem. Bull. 19: 11-15.

Hawkes JG 1990. The Potato: Evolution, Biodiversity \& Genetic Resources, Smithsonian Institution Press, Washington DC.

Islam S, S Miah, W Ahmed, AM Chowdhury, SMM Rahman, K Siddiqui and SMH Kabir (Eds) 2003. BANGLAPEDIA, National Encyclopedia of Bangladesh. Asiatic Society of Bangladesh 8: 149-153.

Lakhanpaul S, S Chadha and KV Bhat 2000. Random amplified polymorphic DNA (RAPD) analysis in Indian mung bean (Vinga radiata (L.) Wilczek) cultivars. Genetica 109: 227-234.

Stebbins GL 1971. Chromosomal evolution in higher plants. Addison-Wesley publishing company, California, USA. 208 pp.

Sultana SS and SkS Alam 2007. Differential fluorescent chromosome banding of Solanum nigrum L. and Solanum villosum L. from Bangladesh. Cytologia 72: 213-21.

Welsh J and MMcClelland 1990. Fingerprinting genomes using PCR with arbitrary primers. Nucleic Acids Res. 18: 7213-7218.

Williams JGK, AR Kubelik, KJ Livak, JA Rafalski and SV Tingey 1990. DNA polymorphisms amplified by arbitrary primers are useful as genetic markers. Nucleic Acids Res. 18: 6531-6535.

(Manuscript received on 16 April, 2012; revised on 29 May, 2012) 